\title{
Farmer's perception on climate-related disasters and their impacts to support food farming
}

\author{
Yudi Riadi Fanggidae ${ }^{1 *}$, Saktyanu Kristyantoadi Dermoredjo ${ }^{2}$, and Woro Estiningtyas ${ }^{1}$ \\ ${ }^{1}$ Indonesian Agroclimate and Hydrology Research Institute, Jl. Tentara Pelajar No 1A Cimanggu \\ Bogor, West Java, Indonesia \\ ${ }^{2}$ Indonesian Center for Agricultural Socio Economic and Policy Studies, Jl. Tentara Pelajar 3B Bogor, \\ West Java, Indonesia
}

\begin{abstract}
Changes and extreme climate events have an impact on and cause vulnerability to the food crop sub-sector. Extreme climatic events that have a significant impact on food farming are floods, drought, and pest/disease. The purpose of this study was to determine farmers' perceptions of climaterelated disasters and their impacts to support food farming. The survey and interviews were conducted in Leles Sub-District, Garut Regency in 2019, with the number of respondents was 28 people, were selected randomly. The results of the analysis showed that the climate-related disasters that occurred were pest/disease (43\%), drought (18\%) and floods (11\%). The impact of extreme climates at the study site was a reduction in yields ranging from $5 \%$ to crop failure (puso). According to farmers, climate-related disasters occur as a result of weather factors, broken channels/embankments, excessive upstream water, closed drains, poor drainage and uneven water allocation to each land. The handling of this climate-related disaster by farmers was still limited. Farmers' perceptions, understanding and abilities in managing and anticipating climate disasters are needed in order to reduce the risk of food farming.
\end{abstract}

\section{Introduction}

Climate change is an important issue to discuss along with the occurrence of extreme climatic events, such as strong winds, extreme rainfall, and long droughts, which have a direct impact on human life. Globally, the incidence of climate-related disasters (floods, landslides, droughts, fires, and storms) has increased in the last 20 years [1]. Strong evidence shown by IPCC (2013) that greenhouse gas emissions from various human activities have a major influence on climate change that occurs and are correlated with the increasing incidence of climate disasters [1,2]. Changes and increases in climate disasters have an impact on agricultural activities and affect food availability [3]. Climate disasters that occur can cause a decrease in food production, even crop failure. Farmers in developing countries are particularly affected due to their dependence on climatic conditions [4].

The incidence of disasters in Indonesia has increased from 2005-2015 [5], Garut Regency is one of the areas with frequent disasters. Based on BPS data from 2011-2020, the dominant

\footnotetext{
* Corresponding author: yrf yudi@yahoo.com
} 
disaster in Garut Regency are related to hydrometeorological disasters, namely floods and landslides [6,7]. The area of Garut which is most prone to landslides is Leles Sub-District, which has a hilly and sloping topography. Land management that does not consider environmental aspects and with steep slope conditions increases the potential for landslides in the rainy season $[8,9]$, this is exacerbated by extreme rainfall that occurs more frequently.

Climate change can threaten the success of national food production [10]. Adaptation steps and mitigation against the events of the climate need to be done to minimize the impact and risk if a disaster occurs. Various research related to climate change adaptation and mitigation that can be done by farmers have been carried out by varying conditions of climate and natural resources that are available $[11,12]$. The implementation of strategies with technology and the right way of thinking by paying attention to environmental aspects in dealing with climate problems has proven to be able to increase agricultural efficiency and can help reduce the impact of climate change in the future [13]. Pest attacks and hydrological disasters such as droughts and floods are increasing in the last 10 years in Leles sub district [7] have a direct impact on the decline in food crop production in that area [14]. On the other hand, there are the result of studies related to technology and adaptation strategy that can be applied to overcome these problems $[3,13,15]$ considering the availability of information system in weather forecasting. The result of study about information and technology must be disseminated to the farmer level to increase the adaptation capacity of farmers, minimize losses due to climate disasters, and can maintain the sustainability of food availability. The information available through mass media such as radio, television as well as system information that can be accessed through mobile phones is not a difficult thing when information and technology are more advanced as it is today. The role of agricultural extension workers is also very important in explaining the information received by farmers so that the transfer of technology to farmers becomes fast increasing and optimal.

One of the factor that hinder information and technology to be applied by farmers is their perception on climate $[16,17]$. Perception that does not correspond to reality will make it difficult for farmer to receive information and change the culture to cope with climate condition. According to [18] the level of education significantly influences the ability of farmers to adapt to climate change. In different region the significant influencing factor could be different, due to the social and cultural differences. This article aimed to determine farmers' perceptions of climate-related disasters, as well as their impact on agricultural activities to help food farming in Leles subdistrict. Understanding the perception of farmers can provide an overview of the level of understanding of farmers related to the events of the climate and the steps to do to overcome it, as well as the factors that affect the process of adaptation of farmers. The purpose of this study is to determine factor that influence farmers' perceptions of climate-related disasters and their impacts to support food farming. This information can help facilitate communication and devise adaptation strategies to support food farming.

\section{Methodology}

The research was conducted in 2019 in Leles Sub-District, Garut Regency, West Java Province. The types of data used in this research were primary and secondary data. The primary data was sourced from interviews of farmers through a questionnaire. The interview was conducted by the method of in-depth interviews. In addition, extracting information was also done through discussion with the Food Crop Agriculture Department of Garut Regency. The determination of location was using purposive sampling. The numbers of respondents were 28 people which were selected randomly from several villages in Leles Sub-District, Garut Regency. The secondary data used was the data of production, productivity and acreage of Garut, derived from the Indonesian Agricultural Data Center \& Information System. 
Monthly rainfall data obtained from Meteorology, Climatology, and Geophysical Agency $(\mathrm{BMKG})$ and the agro climate data obtained from Indonesian Agro climate and Hydrology Research Institute (IAHRI).

The questionnaires were prepared to get the information about the characteristic of farmers which include age, education, and duration of farming. The characteristics of the climate include patterns of precipitation, the beginning of the Wet Season (WS) and Dry Season (DS) as well as the period. The characteristics of a farm include the type of land, land area, productivity, and cropping pattern. Climate-related disasters that occur at the site also became a part of questions in questionnaires including what the cause of the disaster was. At the end of the questioner asked about the types of information and the sources of information related to the climate, the challenges and expectations of farmers in doing the farming. The results of the questionnaires further categorized, analysed, and perform interpretation results.

To find out farmers' perceptions of climate-related disasters, an analysis of the influencing factors was carried out. In this study, the influencing factors are age, education, and length of farming, change of planting date in WS and DS, as well as climate information. The analysis used the regression method with the following equation:

where:

$$
Y=f\left(X_{1}, X_{2}, X_{3}, X_{4}, X_{5}\right)
$$

$\mathrm{Y}=$ Perceptions on the level of impact of climate-related disasters

$\mathrm{X}_{1}=$ Age (years)

$\mathrm{X}_{2}=$ Education (years)

$\mathrm{X}_{3}=$ Length of farming (years)

$\mathrm{X}_{4}=$ Change of planting date in WS and DS ( $1=$ low, $2=$ medium, $3=$ strong $)$

$\mathrm{X}_{5}=$ Climate Information (1=easy, $2=$ difficult $)$

\section{Result and discussion}

\subsection{Profile of the study sites}

Based on the Atlas of Agro climate Resources [19], show that Garut Regency is generally a fairly wet area (Figure 1). The climate type of Garut Regency is moderate and wet with a rainfall range of 1500 to more than $2500 \mathrm{~mm} /$ year. The distribution of monthly rainfall shows the range of rainfall between $82-367 \mathrm{~mm} /$ month, with an average of $256 \mathrm{~mm} / \mathrm{month}$. The highest rainfall occurs in January and the lowest in August (Figure 2). Wet areas are generally located in the south, while areas with a moderate climate are mostly located in the northern part of Garut Regency. Especially for Leles Sub-District, it is in the medium rain type with 3-7 months dry months and 5-9 months wet months with the potential for rice planting index 2 times. Leles Sub-District is at an altitude of 700-1500 m above sea level with air temperature about $18.1-28.4^{\circ} \mathrm{C}$. Based on agro climate resources map, the choice of commodity groups that can be cultivated in this region include cereals (rice, maize, etc.), beans (soybeans, red beans, green beans, peanuts, etc.), yams (cassava, sweet potatoes, ginger, etc.), upland vegetables (potatoes, cabbage, carrots, tomatoes, sweet corn, beans, onions, garlic, eggplant, etc.) and upland plantations (tea, quinine, arabica coffee, cocoa, etc.). 


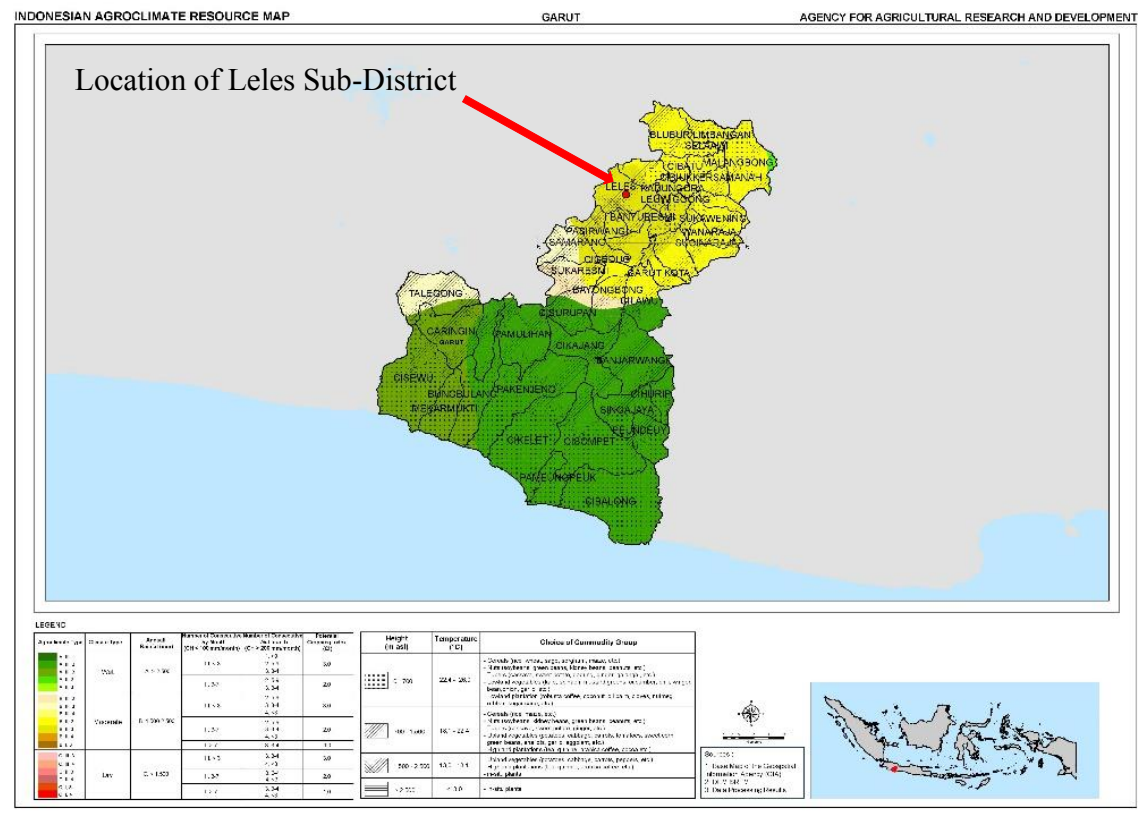

Fig. 1. Agroclimate Resource Map of Garut Regency

(Source: Indonesian Agroclimate and Hydrology Research Institute)

\subsection{Farmer characteristics}

The results of the survey and interviews showed that the respondent farmers in Leles SubDistrict were generally quite elderly, namely $40-50$ years $(39 \%), 51-60$ years $(39 \%),>60$ years $(18 \%)$ and only $4 \%$ were aged $<40$ years. Most of the farmers' education level was elementary school (57\%), the rests were junior high school (18\%) and senior high school $(25 \%)$. This data is same as the previous result stated that the level of education of majority residents in Leles sub district are elementary school [8]. Most of the respondents' farms are rice farmers. The length of farming of the respondents varied from $<10$ years to $>40$ years, but most of the respondents in the Leles Sub-District had cultivated farming between 10-20 years (36\%) and 21-30 years (32\%). The dominant cropping pattern of the respondent farmers is paddy-paddy-paddy. Around $43 \%$ of respondent farmers cultivate paddy 3 times a year, especially in the region of assured availability of water. For other areas where the availability of water is only possible during the rainy season, the cropping pattern cultivated by farmers is paddy-vegetables.

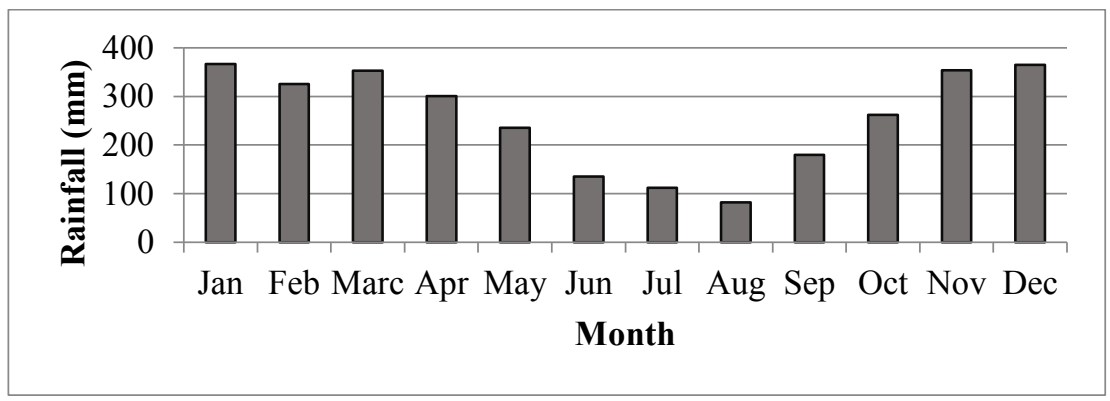

Fig. 2. Monthly rainfall pattern in Garut Regency

(Source: Meteorology, Climatology, and Geophysical Agency) 
Based on the area of rice fields cultivated, $79 \%$ of respondent farmers in Leles SubDistrict have very limited land, namely $0.5 \mathrm{Ha}$. The remaining farmers have the land about 0.5-1.0 $\mathrm{Ha}(14 \%)$ and 1.1 to $2 \mathrm{Ha}(7 \%)$. Rice productivity ranges from $<3$ to $>6$ tons $/ \mathrm{ha}$. In the wet season, the rice productivity of the respondent farmers is mostly $4-5$ tons/ha $(32 \%)$ and $>6$ tons/ha $(32 \%)$. Based on the average result of 28 respondents, it was known that the production of respondents during WS was 5.2 tons/ha and the average during DS was 4.2 tons/Ha. Generally, respondents in Leles Sub-District, Garut Regency, stated that the production at the time of DS was lower than that of WS. For the region of assured availability of water, it is possible that higher production in the dry season, because photosynthesis with sufficient radiation intensity can provide optimal results for plants.

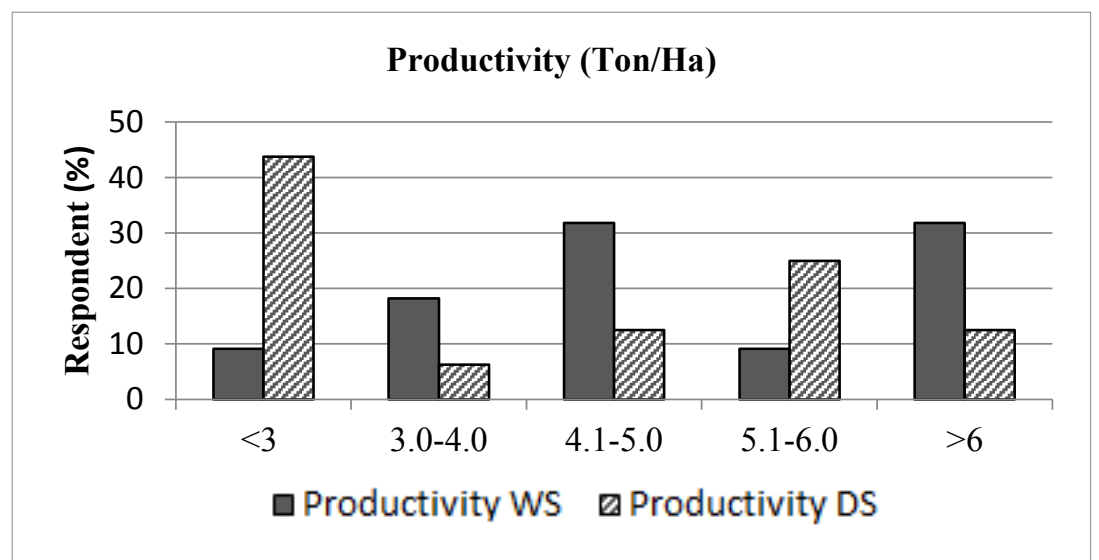

Fig. 3. Rice Productivity in Wet Season (WS) and Dry Season (DS) in Leles Sub-District, Garut Regency

The dominant production of respondents in WS was between 4.1-5 tons/Ha (32\%) and $>6$ tons/Ha (32\%), while in DS, rice production was mostly $<3$ tons/Ha (44\%) (Figure 3 ). As an illustration, based on Indonesian Agricultural Statistics data for the period 1986-2017 [14], the average productivity of rice in Garut Regency was 4.6 tons/ha, the average rice harvest area was $130297.8 \mathrm{ha} /$ year, and the average rice production is 667509.5 tons/year.

\subsection{Perception of climate-related disasters}

In connection of beginning season, based on farmer perceptions, the beginning of WS occurred from September to January, while the beginning of DS was from February to August. The majority of respondents (32.1\%) stated that the start of the WS is September, while the beginning of the DS is May (46.4\% of respondents). An understanding of the beginning of WS is important related to the determination of planting time. The determination of the proper planting time in farm management is required to adapt to climate change $[3,20]$, mainly related to a shift in rainfall patterns [21]. Changes in precipitation patterns have an impact on the availability of water, so that the time of planting that does not adjust with the beginning of the WS will have an impact on crop failure and decreased production (Unit). The determination of the time of planting by the beginning of the WS is proven to give results in better production [22].

Based on the identification results, climate-related disasters that occurred in the research location were flood, drought, and pest/disease. Pest/disease attacks were the most common disasters in the study area $(69 \%)$, the remaining $15 \%$ of respondents stated that they had experienced flooding and $15 \%$ of respondents experienced drought. The impact of climate 
variability visible in the form of the shift of the beginning of the WS and DS [12]. This is reinforced by the results of interviews showed that the majority of respondents stated there is a shift in the start of the season, both in WS and DS during the last 5-10 years. About $66 \%$ of respondents declared the beginning of WS is often backward and $48 \%$ of respondents declared the beginning of the DS was more often advanced. The impact on food farming is in the form of reduced harvest area and production.

In conjunction with climate-related disasters, most of the farmers stated that they had experienced disturbances to their rice crops with varying degrees of damage. The dominant types of climate-related disasters that occurred in the location were pest/disease attacks $(69.2 \%)$, the rest were floods $(15.4 \%)$ and drought $(15.4 \%)$. Climate disasters can directly affect rice production in the affected areas [23]. These results were in line with previous studies related to climate disasters which state that floods, droughts, pest/disease attacks are factors that greatly influence food production $[24,25]$. The increase in extreme weather events due to climate change is predicted to cause a decrease in agricultural production in the future $[21,24,26]$.

Table 1. Regression analysis result of farmer perception on Climate-Related Disasters

\begin{tabular}{|l|l|l|l|}
\hline \multicolumn{1}{|c|}{ Variabel } & Coefficients & P-value & \\
\hline Intercept & 1,431401 & 0,500808 & \\
\hline $\mathrm{X}_{1}=$ Age & $-0,03933$ & 0,342846 & \\
\hline $\mathrm{X}_{2}=$ Education & $-0,07989$ & 0,427494 & \\
\hline $\mathrm{X}_{3}=$ Length of farming & 0,02614 & 0,338699 & \\
\hline $\mathrm{X}_{4}=$ Change of planting date & 1,790108 & $3,39 \mathrm{E}-06$ & $* * *$ \\
\hline $\mathrm{X}_{5}=$ Climate Information & $-0,35212$ & 0,587927 & \\
\hline$* * *$ significant $>99 \%$ & & & \\
\hline $\mathrm{R}$ Square & 0,71223 & & \\
\hline
\end{tabular}

The results of the regression analysis showed that farmers' perceptions of climate-related disasters were influenced by several factors, including: age, education, old farm, change of planting date in WS and DS, and climate information. Among the five factors of the perception of farmers on the impact of disasters most influenced significantly by the initial shift in planting (advanced or backward). It means when the farmer felt or experienced a shift in the season both WS and DS, then this will affect the perception of farmers to climaterelated disasters. The more often shift in the season, farmers perception on climate-related disasters will increase due to the perceived of the impact will also be greater. This result is very significant with a confidence level of $>99 \%$ and R square 0.7 (Table 1). The ability of farmers to adapt by changing the planting dates to adjust with climatic conditions is the key to reducing the risk of climate-related disasters. Changing planting dates is the major adaptation measures to climate change impacts [27]

According to respondent farmers, the causes of climate-related disasters they experience include limited water availability (20\%), channel conditions (15\%), climate/season $(12 \%)$, land changes $(3 \%)$, poor seeds $(3 \%)$.) and the rest $(47 \%)$ respondent farmers said they did not know the cause. Changes in the pattern and intensity of rainfall and the increase in air temperature are factors that cause climate disasters to increase. The beginning of the season and the changing amount of rainfall, causing an increase in the incidence of hydrological disasters, floods, and droughts [26]. Improper planting timing and water management will have a direct impact on production. The increase in air temperature that is suitable with 
moisture increases the potential for the emergence of pest and disease, it is aggravating food crop farming $[25,26]$.

To obtain information related to climate/weather, respondent farmers stated that it was easy for them to obtain information. The main source of information $(68 \%)$ was the mass media (TV/radio) which broadcasts weather/climate forecast information from the BMKG. The rest were through newspapers and agricultural extension workers. Climate-related information is important for farmers to help planning, especially in the determination of the beginning of planting $[28,29]$. Climate information can be used in the agricultural sector in making plans or patterns of agricultural activities, for example, land use planning, cropping pattern planning, determining the commodities/varieties be cultivated, and anticipating steps such as preparing adaptation technology and water infrastructure to reduce losses if they have the opportunity to occur climate disaster [30]. The Cropping Calendar Information System from Indonesian Agroclimate and Hydrology Research Institute (IAHRI) is a form of integration and adjustment of planting time according to climatic conditions which can be a source of practical information so that farmers can directly use it in adapting to climate variability [31].

Food farming in particular is a major source of income for farmers in the District. However, in doing farming, farmers are experiencing obstacles and challenges. According to respondent farmers, the main challenges are pest/disease attacks (25\%) and lack of capital availability $(22.5 \%)$. Pest/disease attacks are increase with the shift in the season [32]. Technology pest and disease control integrated eco-friendly needs to be socialized more intensive and implemented, considering the disorders pest/disease dominant experienced farmers in the District. Limited capital is a classic problem often experienced by farmers. The agricultural insurance program can be an option for disaster-prone locations related to climate disasters as well as the need to provide insight into farming management [33,34]. Other challenges farmer experiencing are the availability of fertilizers, seeds, climate, water sources, help that is not well targeted, infrastructure, and the low selling price of rice (Figure 4). The results of the identification of challenges in farming can be used as input suggestions for the Regional Government of Garut Regency and Leles Sub-District to help farmers minimize the risk. Regarding water sources and infrastructure, in general, the availability of water through the drilled wells, pumps, dams, dams, trenches, etc., including irrigation canals and their repairs. The availability of quality and labelled fertilizers and seeds is one of the guarantees for obtaining the good crop yields. Farmers also need to be given skills on how to make good seeds and utilize waste straw and livestock manure into fertilizers that can help the plant growth.

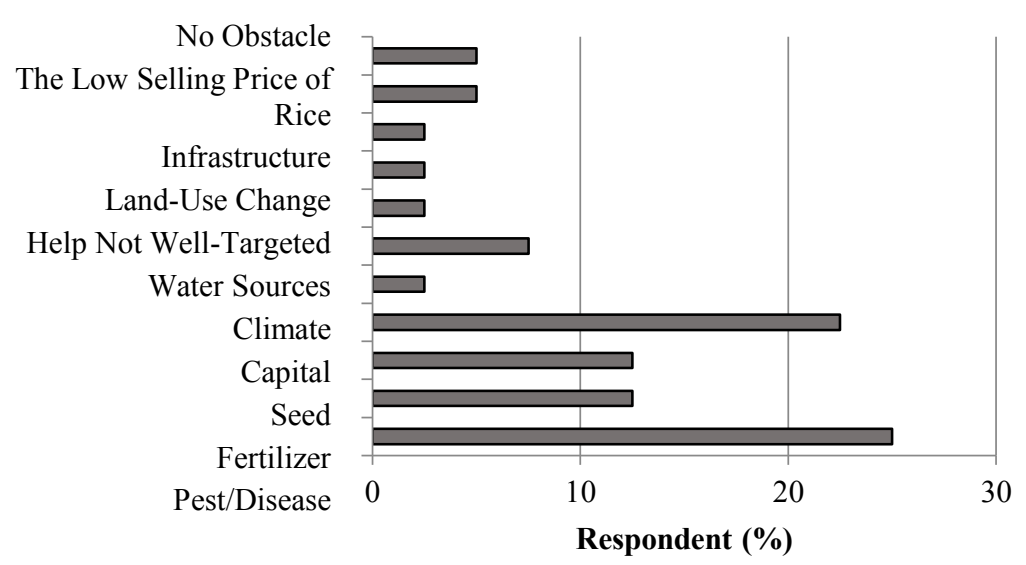


Fig. 4. The challenge of food farming according to Respondent Farmers in Leles Sub-District, Garut Regency

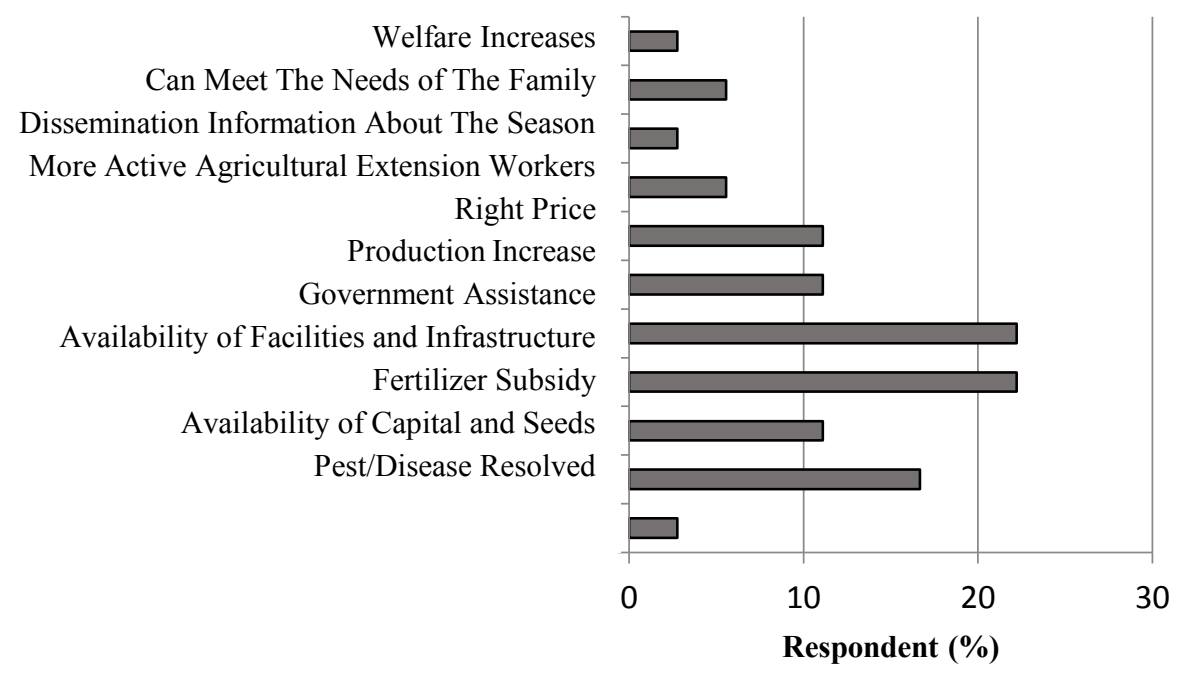

Fig. 5. Farmer's expectation on rice cultivation in Leles Sub-District, Garut Regency

Besides the challenges, identification of the expectations of farmers in carrying out their farming was also carried out. Facilities and infrastructure, as well as government assistance, are the expectations of most farmers, each with $22 \%$. Capital and available seeds are also the hope of about $16.7 \%$ of respondent farmers. Prices are appropriate, fertilizer subsidies and production increases are also hope for farmers each $11 \%$. In addition, farmers also hope that pest/disease can be resolved, there is socialization about the season, and an increase in the role of extension workers in providing information to support food farming (Figure 5).

Based on the results of the aforementioned studies, food farming is greatly affected by disasters related to the climate of flood, drought, and pest/disease. On the other hand, food farming is still mostly done by farmers who are no longer young and have relatively low education. This will greatly affect the capacity of farmers in coping with the impacts of climate-related disasters. Given a large number of responses from farmers to climate-related disasters and their impact on food farming, it is necessary to pursue concrete activities both from the technological aspect and to increase the capacity of farmers to support adaptation to climate change [35]. According to [36], steps to increase adaptation efforts have various possibilities both in terms of form (managerial, financial, technical), scale (local, regional, global), and the participants involved (farmers, industry, government) so that need to be carefully adapted to meet the needs of specific locations and situations.

To reduce the risk it is important to evaluate the effectiveness of adaptation strategies based on different types of farming, location, stimulation of the climate, and economic conditions, political and institutional [36,37]. In addition, the ability to overcome poor people in rural areas is low, especially in marginal areas, hence the need to mainstream the practicegood practice for climate change adaptation into the planning of sustainable development [38].

Farmers' perceptions of climate-related disasters are greatly influenced by the magnitude of the impacts felt by farmers. This information is important for policymakers in the regions in determining priority activities and programs to support food farming. Constraints and 
challenges in food farming are a shared responsibility between the government and farmers as farming actors by involving the private sector to support food farming.

\section{Conclusions}

Food farming in Leles Sub-District is dominated by farmers with the age of more than 50 years and education level equivalent to elementary school. This condition greatly affects the capacity of farmers in managing their farms and to cope with climate change.

The most common climate-related disasters were pest/disease attacks (69\%), floods $(15 \%)$, and drought $(15 \%)$. The impact on food farming is in the form of an initial shift in WS and DS. Farmers' perceptions of climate-related disasters are influenced by several factors, the main one being the initial shift in planting (forward or backward). A fairly long shift from WS and DS will affect perceptions of the impacts of climate-related disasters.

It is important to know the response of farmers to climate-related disasters so that anticipatory actions can be taken against their impacts so that they can reduce the risk of food farming.

Acknowledgement. This paper is part of the research funded by the DIPA of Indonesian Agroclimate and Hydrology Research Institute (IAHRI) in 2019. The authors would like to thank all those who have helped in this research. The main contributor of this paper is Yudi Riadi Fanggidae, while the member contributors are Saktyanu Kristyantoadi Dermoredjo and Woro Estiningtyas.

\section{References}

1. V. Thomas, R. LLpez, Global Increase in Climate-Related Disasters, (ABD, 2015)

2. B. Somboonsuke, B. Phitthayaphinant, S. Sdoodee, C. Kongmanee, Kasetsart, J. Soc. Sci. 39 (2018)

3. C. Harvey, M. Saborio-Rodríguez, M. Martinez-Rodríguez, B. Viguera, A. ChainGuadarrama, R. Vignola, F. Alpizar, Agric. Food Secur. 7 (2018)

4. B.Y. Fosu-Mensah, P.L.G. Vlek, D.S. MacCarthy, Environ. Dev. Sustain. 14 (2012)

5. M.B. Santoso, A. Buchari, I. Darmawan, Soc. Work J. 8 (2019)

6. BPS, Kabupaten Garut dalam Angka, (2020)

7. BPS, Kabupaten Garut dalam Angka, (2021)

8. F. Arsyad, D. Kuswanda, M. Mildawati, Soc. Work J. 4 (2020)

9. M.E. Fauzan, A. Damayanti, R. Saraswati, Int. J. Adv. Sci. Eng. Inf. Technol. (2020)

10. I.N. Hidayati, S. Suryanto, J. Ekon. Stud. Pembangun. 16 (2015)

11. Suciantini, W. Estiningtyas, A. Rahman, Agromet. 34 (2020)

12. W. Estiningtyas, Suciantini, S.K. Dermoredjo, IOP Conference Series: Earth and Environmental Science. 653 (2021)

13. D.R. Reaves, J. Soc. Chang. 11 (2019)

14. PUSDATIN. Basis Data Statistik Pertanian. Pusat Data dan Sistem Informasi Pertanian, Available at: https://aplikasi2.pertanian.go.id/bdsp/id/lokasi, (2016)

15. A.S. Cohn, P. Newton, J.D.B. Gil, L. Kuhl, L. Samberg, V. Ricciardi, J.R. Manly, S. Northrop, Ann. Rev. of Environ. and Res. 42 (2017)

16. Z.A. Elum, D.M. Modise, A. Marr, Clim. Risk Manag. 16 (2017)

17. R.R. Banerjee, Nat. Hazar. 75 (2015)

18. M.N. Uddin, W. Bokelmann, J.S. Entsminger, Climate. 2 (2014)

19. Harmanto, I. Las, E. Susanti, A. Pramudia, E. Surmaini, Y. Apriyana, W. Estiningtyas, Suciantini, S.H. Adi, B. Kartiwa, N. Heryani, E.R. Dewi, K.S. Hayati, Misnawati, D. Firda, S.N. Firdhauzi, N.P. Cahya, C. Nengsusmoyo, A. Mulyani, M. Agustian, N. 
Rachmawati, Y.A. Baroto, A. Hervani, H. Alfiani, H. Kurniawan, M.N. Imansyah, W.

Sukendar, Atlas Sumberdaya Agroklimat (Skala 1:500000), (IAHRI, 2020)

20. M. Esham, C. Garforth, Mitig. Adapt. Strateg. Glob. Chang. 18 (2013)

21. Ruminta, Handoko, T. Nurmala, J. Agro. 5 (2018)

22. M. Waongo, P. Laux, H. Kunstmann, Agric. For. Meteorol. 205 (2015)

23. M.F. Stuecker, M. Tigchelaar, M.B. Kantar, PLoS One 13 (2018)

24. I.M. Sudarma, A.R. As-syakur, SOCA J. Sos. Ekon. Pertan. (2018)

25. J. Jiang, X. Xiab-Bin, Y. Hayashi, F. Tao, Tsukuba Geoenvironment. Sci. 3 (2007)

26. R. Wassmann, S. Jagadish, K. Sumfleth, H. Pathak, G. Howell, A. Ismail, R. Serraj, E. Redona, R. Singh, S. Heuer, Advan. in Agron. 102 (2009)

27. A.H. De-Graft, E.E. Onumah, Agris On-line Pap. Econ. Inform. 3 (2011)

28. W. Estiningtyas, Suciantini, E. Susanti, Tropical Wetlands Innovation in Mapping and Management, Proceedings of the International Workshop on Tropical Wetlands: Innovation in Mapping and Management 2018, (2019)

29. W. Estiningtyas, A. Hamdani, J. Meteorol. dan Geofis. 16 (2015)

30. E. Aldrian, J. Sumberd. Lahan, 10 (2016)

31. Y. Apriyana, E. Surmaini, W. Estiningtyas, A. Pramudia, F. Ramadhani, Suciantini, E. Susanti, R. Purnamayani, H. Syahbuddin, Sustain, 13 (2021)

32. M. Abid, J. Schilling, J. Scheffran, F. Zulfiqar, Sci. Total Environ. 547 (2016)

33. W. Estiningtyas, I. Las, H. Syahbuddin, Politik Pembangunan Pertanian Menghadapi Perubahan Iklim (IAARD Press, 2013)

34. W. Estiningtyas, J. Sumberd. Lahan, 9 (2015)

35. W. Estiningtyas, Y. Apriyana, C. Nengsusmoyo, Seminar Nasional Adaptasi dan Mitigasi Perubahan Iklim (2017)

36. B. Smit, M.W. Skinner, Mitig. Adapt. Strateg. Glob. Chang. 7 (2002)

37. D.L. Ficklin, Y. Luo, E. Luedeling, M. Zhang, J. Hydrol. 374 (2009)

38. S. Mehta, V. Kumar, R. Lal, Handbook of Sustainable Development in Asia (Routledge 2018) 